\title{
Chapter 10 \\ Theoretical-Methodological Elements for Comparative Analysis of Social Inequalities in Life Courses
}

\section{Leticia Muñiz and Joan Miquel Verd}

\begin{abstract}
Social inequalities are one of the structural problem areas of Western capitalist societies, and are of particular relevance both in Europe and in Latin America. Sociological studies on the issue account for the complexity of the phenomenon by presenting their constitution and consolidation based on the analysis of institutional and subjective aspects, which include the particularities, on the one hand, of the socio-economic systems of countries and regions; and, on the other hand, the representations, dispositions and actions deployed by individuals in order to deal with and live in an unequal world.

This chapter forms part of these discussions on social inequalities by developing a theoretical-methodological analysis that helps to generate critical views of the phenomenon in a context in which there is a need to design public policies that will foster equality. In particular, social inequalities are studied from the perspective of life courses, which involves multidimensional analyses over time; and a theoreticalmethodological model that deepens our current knowledge of the Comparative Biographical Perspective is developed. In order to show how this approach can be used empirically, we then present an analysis of the career paths of workers with different levels of education in Argentina and Spain.
\end{abstract}

Keywords Life course $\cdot$ Social inequalities $\cdot$ Spain $\cdot$ Argentina $\cdot$ Comparative biographical perspective $\cdot$ Theoretical-methodological model

\footnotetext{
L. Muñiz $(\bowtie)$

Instituto de Investigaciones en Humanidades y Ciencias Sociales, Universidad Nacional de La Plata,

La Plata, Argentina

e-mail: lmunizterra@conicet.gov.ar

J. M. Verd

Centro de Estudios Sociológicos sobre la Vida Cotidiana y el Trabajo - Instituto de Estudios del Trabajo, Universidad Autónoma de Barcelona, Barcelona, Spain

e-mail: JoanMiquel.Verd@uab.cat
} 


\subsection{The Longitudinal Dimension of Social Inequalities}

\subsubsection{Study of Inequalities: Between Structure and Social Action}

The study of inequalities as a social phenomenon has its origin in the fall of the Ancient Regime and in the advent and expansion of the capitalist system. Since then, widespread debates in the social sciences have been generated around the ideas of equality and freedom, which emerged as central components of the new social order. The controversies that arose around them were associated from the 19th and 20th centuries with discussions sparked by liberal and radical ideological currents around freedom and equality. While liberal movements have sought to defend individual freedom to foster subjects with individual rights in society, the critical movement, and more directly Marxism, has conferred greater weight upon equality with the intention of fostering the collective distribution of the social product.

With the passage of time, this theoretical debate faded, and to a large extent failed to solve the most fundamental issues. It was not until the 1970s that the concern for social equality and its opposite number, inequality, was revitalised as the complexity of the problem became apparent and empirical studies revealed the emergence of new forms of social inequality in industrialised countries and the impossibility of achieving absolute equality in socialist ones. Hence, the core issues in the social sciences were oriented both towards analysis of the historical and social conditions required to form a more just society, and towards studies of the constant growth of social inequality and the possibilities of reducing it. It was in that context that theorisations emerged regarding the intrinsic characteristics of equality/inequality, leading to views focused on individuals, relationships and macrosocial contexts.

The perspectives that emphasised individual experiences stressed the unequal distribution of capacities and resources among individuals and in some cases called for meritocracy and equal opportunities as a way to combat inequality in a competitive context (Rawls 1997). Interactionist views, on the other hand, noted that inequality is reproduced within the framework of social relations, where individual capacities and potentialities translate into power struggles. They were especially concerned with the study of the social links that generate inequalities, which can refer either to the interactions between different actors that impose heavy restrictions (Goffman 1981), or to distinctively confined categorical pairs such as woman/ man, citizen/foreigners, aristocrat/commoner, etc., that can persist throughout a career, life or organisational history (Tilly 2000). They therefore focused mainly on analysing the relationships between unequal inter-institutional exchanges and actors, for it is these that engender chains of dependence, methods for exploitation, resource grabbing, exclusion processes and other forms of power relations that cause the flow of wealth from certain groups to others. 
Finally, studies focused on structural conditioning focused on the structures that unequally distribute the benefits and burdens among the different sectors and individuals that make up a society. They assume that economic and social structure cause individuals to be placed in different parts of society and that the macro-context fundamentally explains the existence of social inequality (Bárcena and Prado 2010). This view then increases the weight of those economic, political, social and cultural conditions that cannot be modified through mere human agency and in the short term, and that go on to form the persistent inequalities and asymmetric positions that are imposed upon the affected groups.

From the previous paragraphs, it is evident that each of the analyses and theorisations on inequality that we have mentioned focused on different aspects and dimensions of the phenomenon, engendering explicit or implicit debates on freedom and equality, and shedding light on some particular aspects of the phenomenon of inequality, without proposing a holistic view of the problem. To tackle this analytical fragmentation, some more recent studies have proposed the recovery of the multidimensionality of social inequality (Therbon 2006; Wilkinson and Pickett 2009; Savage 2014; Reygadas 2004). Although these perspectives come from different theoretical positions, it is interesting to note that they all propose an analysis oriented towards analytical integration that can address, though not necessarily resolve, the existing tension in sociological studies between social action and structure. They therefore propose an integrated vision to foster coordination/tension between macro-structural conditioning (macro social scale), institutional policies and relations (mesosocial scale) and the actions of individuals (microsocial scale). Each of these scales is composed of different dimensions (education, labour, religion, politics, etc.) that are often interconnected. The way in which the many scales and their dimensions are linked thus gives rise to a specific social inequality. This configuration also offers the particularity of being changeable, for it can be transformed diachronically. The particular coupling of the many scales and dimensions over time and in specific contexts (historical, cultural, etc.) leads to permanent production and reproduction of social inequality.

\subsubsection{Life Course Transitions as Excellent Vantage Points for Observing Inequalities and Social Protection Actions}

The previous section concludes that an analysis of inequalities requires taking into account the multiple scales and dimensions in which they occur, and particularly the links between the macrosocial, mesosocial and microsocial levels. The biographical perspective offers unrivalled methodological advantages, as it is not too difficult to link aspects that are situated on the macrosocial level (structural processes and conditions and contexts of action) with the mesosocial level (the role of institutions) and the microsocial level (practices, representations, experiences and strategies, if any, of an individual nature). 
But the diachronic dimension of inequalities should also be considered, since it is this that can identify the way in which inequalities increase or decrease over time, and also how they are reproduced and transmitted between generations. Here, the biographical approach is intrinsically diachronic, since our lives are, by definition, longitudinal and not cross-sectional. In a context in which biographies are far from being stable, i.e. there are countless situations that produce sudden and unexpected changes in people's lives, the longitudinal perspective is essential. In fact, some concepts used in the last 15 years to explain situations of inequality, such as 'entrapment', 'scarring effect' and 'cumulative disadvantage' are fundamentally longitudinal. However, most analyses of inequality are still conducted with cross-sectional data.

In Western countries, while there is less 'social determinism' in life courses (in the sense that some variables, such as gender or level of education, which in the past had a marked influence on the kind of life someone could expect, are now not such strong determinants of one's path in life) and greater diversification of the life itineraries, it is also becoming increasingly easier for specific events to have a negative impact on them. The study by Vandecasteele (2010) of cumulative disadvantage shows that having a child, a member of the household losing their job, or a couple breaking up have an effect that can trigger poverty situations (the former, fatherhood or motherhood, only in specific cases). These events mark biographical turning points regardless of the classic variables of social structure, although the negative effect is reinforced by the fact of being on the more at-risk side of the social structure. The findings of this research suggest two relevant conclusions in relation to the study of inequality and public policies aimed at eliminating it. On the one hand, it is observed that in the processes of cumulative disadvantage, factors situated at the macro and mesosocial levels are interrelated with the events that take place at the individual level, something that has already been noted in the previous section of this chapter. It thus follows that the analysis of inequality should consider the three levels and employ methodological procedures that allow for an understanding of the relationship between them. The second finding is the dire consequences of the absence of support and resources at specific moments of life courses, which can constitute negative turning points whose impact is prolonged over time if public policies do not adequately compensate for them.

The proposals made by Schmid $(1998,2006)$ show the importance of taking life transitions into account in the design of social protection policies. His work on Transitional Labour Markets (TLM) is frequently cited as an example of the importance of adopting a longitudinal perspective in the design of public policies, especially as a "guide to the analysis, management and coordination of existing and future labour market policies" (Vielle and Walthery 2003: 81). The author begins by proposing five main types of transition linked to labour markets (see Schmid 1998: 10-11): (1) transitions between short-time work or part-time work and full-time employment, or transitions between dependent work and self-employment; (2) transitions between unemployment and employment; (3) transitions between education or training and employment; (4) transitions between domestic and care work and paid employment; and (5) transitions from employment to retirement. These transitions are not viewed in a single direction, but in both (except perhaps, that between 
employment and retirement). The author then presents a series of criteria for assessing the extent to which employment policies and social welfare mechanisms are able to offer instruments that avoid potential situations of biographical risk in people's working lives (2006: 9-19).

The study by Anxo et al. (2010) also highlights the importance of investigating social welfare systems from the perspective of key life transitions. These authors justify their attention to transitions between life stages for three reasons: (1) it provides a lens through which to analyse a range of different interrelated dimensions of social welfare systems, such as the family and employment; while also identifying their effectiveness in relation to different social groups defined, for example, by class, gender, age or generation; (2) it can identify the consequences of the reforms being made to employment and social welfare systems, thus showing who benefits and who loses as a result of said reforms; and (3) it can guide interest in societal and institutional effects on life trajectories through consideration of the plurality of support needs derived from increasingly more variable life courses.

Given the importance acquired by the concept of transition for the type of analysis we propose, we adopt the definition given for the Life Course Perspective (Elder 1985; Giele and Elder 1998; Mortimer and Shanahan 2004). From this perspective, the concept of transition refers to changes in status that occur in short periods of time throughout a life course. This notion is different from that of a turning point, which implies "a substantial change in the direction of one's life, whether subjective or objective" (Elder, Johnson and Crosnoe 2004: 8). So, not all transitions involve turning points, since the change of status involved in transitions may be far removed a shock or disruption to the life course, which is what characterises turning points. In short, whether a change constitutes a turning point or not largely depends on personal characteristics or resources and on the external support available to that person in order to adapt to the change, as shown above in the studies by Vandecasteele and Schmid. These turning points also "reflect the effective exercise of agency in both creating and responding to new opportunities" (Bynner 2005: 379).

The Life Course Perspective is interested in the sequence of events that have marked a life course from an aggregate perspective, taking as the focus of the analysis one or several generations or cohorts. As Runyan (1984: 82) points out, the orientation "puts greater emphasis on the influences of changing social, demographic, and historical conditions upon the collective life course". This has led researchers who use this perspective to mainly, but not only, work with quantitative data. Casecentred qualitative studies are in the minority compared to variable-centred quantitative studies. However, the fact is that in order to make full use of the given analytical advantages, a qualitative approach must at least partially be adopted.

A qualitative methodological approach can identify those events, transitions and stages that constitute real moments of disruption to life courses. In many cases, these moments can only be defined subjectively, since what for one person might be a turning point, may not be for another. It is at these turning points when the role played by social welfare measures can best be evaluated, whereby the role played by the possible resources provided for correcting or reorienting personal histories can be identified. And secondly, the qualitative approach can also examine the 
degree to which life courses are marked by individual decisions or by the influence of structural constraints. It is thus possible to adequately consider the weight that the 'marks' of past episodes have on individual life courses, as well as on an individual's future prospects. Third, the qualitative approach can be used to contemplate social experiences and actions in interaction with the cultural, institutional and even historical context that surrounds individuals, which makes it possible to consider the effects that individual and collective resources have on a life course, and to connect the macro, meso and micro levels in these explanations. Finally, the qualitative approach can also be used to jointly consider the interrelationships between different spheres of life, since the intrinsically holistic and comprehensive nature of qualitative data enables identification of the interactions and connections between these different spheres and contemplation of effects and connections with certain spheres of life that were certainly not contemplated in the initial design of particular measures.

\subsection{A Qualitative and Comparative Narrative-Biographical Perspective}

\subsubsection{The Narrative-Biographical Approach}

Taking the aforesaid qualitative approach necessarily implies a methodology from the narrative-biographical perspective, which has long been a tradition in sociology (Thomas and Znaniecki 1918). The central methodological basis of this perspective is that of narrative-biographical interviews, also known as life stories. In fact, Bertaux (1980: 200) distinguishes, following Denzin, between studies based exclusively on life stories and those in which the story is complemented by information obtained via other sources, such as all kinds of personal documents, interviews with other people, or even quantitative data (life histories). Life stories not only directly collect all aspects related to agency (goals, representations, motivations), but also rich contextual information (Bertaux 1997; Jovchelovitch and Bauer 2000), i.e. what Clandinin and Connelly (1994) call the outward dimension of personal experiences - the conditions of existence, the contexts and events that are 'outside' of the subject. As Bertaux (1997) has noted, life stories can also be used to distinguish between causes that are attributed to circumstances that are external to the subject and those that are attributed to goals or desires that can be found within the perpetrator of the action itself. Following Shütz (1987[1971]), Bertaux calls the first type of circumstances 'because' causes, and the latter 'in order to' causes. These causalities must be passed through the analytical sieve of the researcher, who must assess, precisely using as much contextual information as is available, the margin of freedom that the subjects' environments offer.

Another advantage of using life stories is the possibility of identifying without too much trouble the moments of biographical disruption or turning points that are 
important to individuals. The ideas of crossroads, bifurcations or "points of no return' are constant in biographical narratives. Lahire notes (2002: 30-31, italics from the original) the importance of "drawing out moments of 'biographical disruption', changes or amendments, even slight, in trajectories or careers [...] because they are the moments when provisions can be placed in question or suddenly reactivated when they had previously been dormant". The use of only quantitative data makes it extremely difficult to distinguish between voluntary and involuntary biographical disruptions, and can even be misleading, since transitions can be confused with turning points (Verd and López-Andreu 2011). As argued by Diewald and Mayer (2008), the Life Course Perspective in sociology may too often have considered that trajectories are mostly the result of institutional and structural aspects, whereas individual agency is also a key element in the direction, and changes in direction, of a life course.

A second relevant distinction within the narrative-biographical perspective is the one raised by Rosenthal (2004: 62) between lived life and told life: "the difference between biographical self-presentation at the time of narration and the experience in the past". This distinction between lived events and those that are narratively reconstructed from the present is of major relevance to research that works solely with data from biographical interviews. Bertaux (1997) and Thompson (2004) call themselves 'realists', to emphasise how they are fundamentally interested in lived events, understood as those facts and situations that form the basis of the story. In these cases, the relevance of the story is defended as a means of access to the 'goal' reality beyond the narrator, such that despite the mediation involved in the account of a biography, it is always "possible to reconstruct the diachronic structure of situations and events that have marked this path" (Bertaux 1997: 37; italics from the original). From this 'realist' perspective, the approach adopted by Bertaux (1997) and Thompson (2004) is mainly inductive in nature, while the one adopted in Life Course studies (Elder) is more deductive. This more deductive view is what allows the analysis to be directed towards certain aspects and specific moments of a life story. In the examples in sect. 10.3, this view is partially adopted since we will focus on those elements that influence the development of unequal life and career paths, and on the effects that policies and institutional welfare and training mechanisms have on them.

\subsubsection{Case Studies as a Strategy for the Analysis of Comparative Life Stories}

Case studies are viewed in the social sciences as one of the methodological strategies for the analysis and study of comparative phenomena. Most comparative qualitative studies follow the methodological guidelines of case studies, which have been extended in recent years to various countries and a wide variety of fields (Yin 2014, 1995; Ragin and Becker 1992; Stake 2005; Passeron and Revel 2005; Gerring 2007). 
However, as Piovani et al. (2011) argue, there is ambiguity as to what should be regarded as a case study resulting from disagreements (and even contradictions) in relation to their name, their usefulness for quantitative and qualitative methods and their theoretical basis. These differences became apparent when doing empirical research, and two moments can be defined, differentiated by the theoretical and argumentative treatment by different authors on this research perspective. The first relates to the insertion and validation phase of this type of research within qualitative approaches, a stream that includes the studies by Yin $(1995,2014)$, Eisenhardt (1989) and Stake $(1994,1999)$, who conducted their research from the late 1980s until the mid-1990s. Among the limitations of this first moment, there are debates on the 'generalisation' problem and its theoretical scope (Giménez 2012). The second moment is characterised by a review and extension of the concepts and methodological implications that such studies entail for social research, especially when they are assumed as a strategy for comparative studies.

In particular, the distinction between single and comparative case studies is retrieved here (Yin 2014). While single case studies focus on the uniqueness of the studied unit, due to its particular, crucial, exemplary (typical or extreme) or revealing nature, in comparative case studies, different units are chosen in order to obtain a broader view of the concept and boost the analytical representativeness of the study. Yin's (2014: 57) own distinction between the comparison of cases aimed at literal replication and those aimed at theoretical replication is enlightening. In literal replication, cases are chosen in the expectation of obtaining similar results, since it is felt that they represent different cases of the same phenomenon; on the other hand, in theoretical replication, cases are chosen in the expectation of obtaining different results since some of the key characteristics of the phenomenon differ between them. This logic has points of contact with experimental design (Yin 2014: 57), in which the values of certain variables remain fixed, to check the causal effect of the variables whose values differ between the chosen cases.

The relevance of single or comparative case studies is linked to the possibility that this methodological strategy offers for biographical comparison. In fact, Breckner (2007) has noted that the biographical approach can be seen as a type of research with a design similar to that of case studies, in that their case-oriented logic contrasts with the variable-oriented logic that is so typical of quantitative studies. From this point of view, the goal of comparing cases "is to reconstruct from the complexity of empirical processes patterns which can be theorised as 'general' concerning their relevance in a specific social field" (Breckner 2007: 115). Following this qualitative logic, and unlike quantitative studies, the relevance of the patterns found does not depend on their distribution or numerical frequency, but on their potential to identify the structuring impact of certain circumstances or actions in specific contexts (Breckner 2007).

The comparative biographical perspective (Muñiz Terra and Rubilar 2018) also highlights the importance of deepening the knowledge obtained from the application of the analytical logic of case studies. According to this strategy, the comparative approach focuses on revealing, interpreting and comparing the elements analysed in a single case or in comparative cases that could be called biographical. 
Similarities and differences should be identified between these cases, which should be built on the basis of common research problems, i.e. based on a comparative research problem, biographical case studies that are similar or different in relation to that problem can be delimited.

Likewise, and in line with Przeworsky and Teune (1970), classic authors on quantitative comparative methods, the comparative biographical perspective maintains that it is possible to theoretically understand society if, in addition to noting that social phenomena are diverse and complex, we consider that they occur in independent and interactive structures and in a location in space and time, which reminds us that social processes analysed across time must also be understood within the framework of the spatial contexts in which biographical case studies take place. The identification of spatial contexts is very important because the elements to be analysed can acquire differences depending on the spatial and contextual characteristics present in the phenomena studied.

Especially considering time and space contexts of biographical studies, in this chapter we recover the holistic case studies proposed by Yin (2014) to conduct an analysis based on the systematic and controlled comparison of transitions linked to the labour market as identified with biographical accounts. Given the wealth of information provided by biographical interviews, our proposal helps to avoid the risk of 'cherry picking'; i.e. it avoids selection during the analysis phase of those events that represent evidence in favour of a certain reading of the data, while those that work against that same reading are ignored. So, the type of systematic comparison being proposed obliges the analyst to consider all the evidence, both for and against a given interpretation of the data. To achieve this, the biography is translated and 'stylised' in the form of comparative tables, which collect each of the transitions and classify them by the main analytical dimensions taken from the theoretical framework (see the tables in the appendices). In this one-by-one comparison of transitions, the limitations and influences taken from macrosocial and mesosocial contexts are considered, as well as individual decisions, goals and constraints that allow or impede a certain course of action, and hence a certain development of the life course.

This systematic and systematised analysis allows a comparative biographical perspective that is controlled and guided by the main analytical dimensions considered, which may be intra-configurative or inter-configurative in nature. The intraconfigurative biographical view involves taking a biographical case (i.e. a single case), and the way in which the macro and mesosocial scales are connected/stressed in time in the biography analysed, i.e. the way in which different factors external to the subject condition or propitiate the life history over time and their place in the development of subjective experiences and decisions is studied. The individual's biographical account is thus recovered as a source of fundamental information and the way in which both choices/actions and the consequences of certain structural constraints arise in the biographical narrative are analysed, while also incorporating the researcher's analytical view in relation to the particularities assumed on the macro and mesosocial scales in the configuration of the studied biography. 
Meanwhile, inter-configurative biographical analysis implies the development of a comparative case study in which two or more biographies are contrasted, analysing first the way in which the macro and mesosocial scales condition or favour the life stories in each single case, secondly the relevance that subjects' experiences and choices have along the way, and thirdly the particularities assumed by external conditions and actions in the different stages of the compared life paths.

However, if the focus is on transitions and turning points or biographical bifurcations, we need to ask what dimensions are involved in the biographical comparison, and what kind of comparisons can be made. For the present study, the transitions and turning points to be compared are linked to external factors, whether macro or mesosocial, in that they can show how different biographical cases manage the contingency, linking over time advantages or disadvantages that give rise to unequal life paths. This can reveal, on the one hand, if when faced by the unexpected, biographies are resolved by recurring to institutional supports (social welfare measures) or to individual decisions, thus accounting for the strengths and weaknesses of the welfare systems in which the biographies occur and, on the other hand, helps us to apprehend the different effects that a contingent event can have on the life courses of different individuals.

Finally, two interesting issues to highlight are, on the one hand, that more than one unexpected transition or turning point can occur in a life course and, on the other, that the reorientation that they produce in biographies is not necessarily immediately visible. Hence, it is very important to honour the relevance of diachronic aspects in the biographical comparison, since it is only over time that disruptive events and the reorientations that they cause become evident.

\subsection{Application of the Theoretical-Methodological Proposal to the Comparison of Career Paths in Argentina and Spain}

\subsubsection{Brief Presentation of the Research Conducted in Argentina and Spain}

For the application of biographical comparison, we recur to two studies of career paths conducted in parallel in Argentina and Spain, and which are used here to develop a comparative perspective that will enrich the debate on social inequality.

Both studies started from a common question focused on understanding how formal and informal workers in both countries build their career paths and what particularities occur on those paths depending on their positions in the social structure. At this point, it should be noted that the biographical interviews were able to combine information constructed during the two studies by delimiting a series of dimensions present in the paths, such as: the stages and states of lived life, transitions and turning points, goals to change jobs, institutional resources and the 
employment and welfare systems that were assessed in the collected life stories (see appendices).

For the purposes of the comparative exercise, two different cases were selected from each study to illustrate both the differences and similarities that are apparent in the configuration of career paths as a result of the articulation between the macro, meso and microsocial scales, such as the way in which the chain of advantages and disadvantages and the bifurcating effects that external events are produced, giving rise to a configuration and reconfiguration of particular social inequalities.

\subsubsection{Intra-Configurative Biographical Analysis: Presentation of the Case Studies}

Retrieving the idea indicated above that the intra-configurative biographical approach involves a single case study to analyse the way in which the macro, meso and microsocial scales are connected/stressed in biographies across time, we present below the selected cases to illustrate our proposed intra-configurative analysis, which was conducted on the basis of the set of comparative tables that are included in the appendices.

\subsubsection{Case 1: Enrique's Career Path}

Enrique is a worker from an industrial region in the province of Buenos Aires, who has been forging a zigzagging career, as he has changed jobs several times. Although his first job working informally for a lubricant company involved no specific knowledge, from his second job, in which he learned how to operate a crane (handling of cranes and heavy vehicles) in a company that replaces pipes, he was able to repeatedly switch jobs, almost always using this skill. Operating a crane thus became central to his career since despite not having an official certificate because he had learned the job informally in the workplace, he was recognised and appreciated by companies because there are not many people who have this manual skill. However, a mechanical technician qualification was a central issue as one is required by the industrial firms for which he worked. In Argentina, this training involves taking and passing basic compulsory primary and secondary education, plus industrial orientation. In other words, it involves successfully getting through 7 years of primary school, 5 years of secondary school and one further year more of industrial apprenticeship (mechanics, electricity, carpentry, etc.).

In his story, Enrique says that he has been changing jobs to "to get more cash" and "thanks to having a trade in my hands". So, once he had his mechanical technician certificate and "crane know-how" he started out on a career path that involved changing jobs in search of better pay: he worked at the YPF state-owned oil company, then for two industrial services companies and an important local public 
shipyard, then went back to the state oil company, a company that he finally left in the wake of its privatisation in the early 1990s. That was when his freedom to change jobs in search of better wages was frustrated, given the critical situation faced by the Argentinian labour market. However, this experience is also viewed as a conditioned choice, since it was he who decided to accept the firm's offer of voluntary redundancy. That subjective decision is especially viewed by Enrique as a "personal choice", because although as a union delegate he had protection and could carry on working for two more years, he decided to leave because "the atmosphere in that company was very draining" for him and the amount of money offered for taking redundancy was attractive.

Faced with the great financial crisis and the lack of job offers back in the early 1990s, when he left YPF he decided to invest the voluntary redundancy pay in setting up a workshop at home, for which he needed support from his wife (who until then was dedicated exclusively to domestic and care work) in order to make it profitable. He and his partner were self-employed for approximately 4 years, after which they closed the workshop because Enrique was able to return to the Rio Santiago Shipyard as a crane operator, a change that he highly appreciated because he was able to return to formal employment with all the labour rights. That was his current situation at the time of the interview. His wife has since returned to exclusively doing domestic and care work in their home.

The account of the comings and goings in this worker's career path can in turn be viewed in the light of the structural constraints and the times when the events occurred. Although his narrative only slightly touches on the occupational limitations that he experienced as a result of the crisis in Argentina in the 1990s, it is necessary and possible to make an interpretation that includes that context. It can be noted that although the welfare regime in Argentina characterised by a reduction in governmental involvement in the labour market and a neoliberal economic policy had already begun to be applied by the military government between 1976 and 1983, it was during the welfare regime of the 1990s when there was a brutal policy of 'state shrinkage', privatisation of a large number of public companies, liberalisation of the economy, downsizing of government workforces, reduction in collective bargaining, the advent of flexibility and labour reform that greatly restricted workers' rights, etc., a situation that was reflected in the rise of unemployment to twodigit numbers (Varesi 2009).

It was precisely in those years when Enrique was 'invited' to become an informal self-employed worker, while before then he had always had formal jobs in stateowned companies or unstable work in private companies. This latter issue also seems significant, since it reveals the impossibility of receiving an unemployment benefit to minimally guarantee his reproduction and that of his family, and shows that in Argentina labour rights were commonly (although not always) applied to public jobs in contrast to private jobs. Although Enrique managed to get out of selfemployment by finding formal work, he got this job in one of the few state firms that managed to maintain its public character in exchange for changing jurisdiction, since it went from being national to provincial. 
This worker leaving the oil company can thus be interpreted as a turning point, as it meant a before and after by causing a worker with a trade who had always been able to choose where to work in order to earn good wages to turn into the totally unfamiliar world of unstable work. Finally, his skill as a crane operator and the existence of the local state-owned shipbuilding company meant he could get his career back on track (where he was working in 2009, when he was interviewed) and get out of the subsistence self-employment in which he had taken refuge during the crisis of the 1990s.

\subsubsection{Case 2: Rubén's Career Path}

The story of Rubén, a worker from an industrial region in the province of Buenos Aires, begins early at the age of 14 when he left basic compulsory secondary education (he only took 2 years rather than the mandatory five) due to the need to work to support the family economy. From his first job, his career path was stop-start and always informally in subsistence self-employment, alternating between informal jobs as a drinks distributor, carpenter's assistant, kitchen hand and construction worker, with a short, unstable one-year job on a fixed-term contract as an operator in a company before going on to find formal employment as an agent for state oil company YPF. He worked there for 7 years, always in loading and unloading activities for which very few skills were required, moving up relatively quickly considering the short time he had been an oil worker. The physical work put a strain on his body over these years, and he suffered two accidents at work that caused a reduction in his motor skills.

In the early 1990s, when the state company was privatised, he left the firm by accepting the 'voluntary' redundancy that was offered as part of the downsizing of the YPF staff. He used the money he received to buy a house on the outskirts of the city so he no longer had to pay rent and then started using his limited qualifications to go back to stop-start work, alternating occasional, unstable subsistence selfemployment and construction work with long periods of unemployment. His irregular income was compensated by the main earner in the household, his wife, who worked as a domestic employee. Rubén was frustrated by his difficulties finding more stable work as felt he was not fulfilling what he views as his 'duty' as a male breadwinner. He feels he is "diminished because the one who is keeping the family afloat is my wife".

Although there are no contextual aspects in his account, it can be imagined that in the chain of disadvantages in Rubén's career path, a series of subjective factors are condensed with a series of structural constraints. Middle school dropout correlated in the late 1970s with early entry (at age 14) into a labour market that, as we noted earlier, was at the primary stages of implementation of a welfare system that encouraged a reduction of state intervention to guarantee and promote formal employment during the Argentine military dictatorship. His switching between different informal occupations was only interrupted by the opportunity to work for 
a brief period as an operator in a state-owned company, in which he was however unable to acquire knowledge that he could use after leaving the company. Without specific qualifications, with some reduction in his motor skills and in a national and local context of high unemployment rates (resulting from the implementation of the 1990s welfare system in Argentina), Rubén embarked on a career path that was not only marked by informality but also by long periods of unemployment that he had never experienced before.

Entry in the only formal work that he managed to find and his departure from it as a result of the destabilisation of the company and the downsizing of its staff that that entailed can be viewed as turning points in an informal career path. Joining YPF was thus a before and after. He seemed to be headed for a change of course towards formal labour, but this shift was disrupted by the privatisation of the firm, which became an external event that not only led him into the same informal situation as before but also towards long and recurrent periods of unemployment. This shows how both external bifurcations generate advantages (only during formal employment) and disadvantages that viewed as a chain help to explain the particularities and the direction that Rubén's informal career path was taking when he was being interviewed (in 2008).

\subsubsection{Case 3: Andrés' Career Path}

Andrés is from an eminently working class town on the outskirts of Barcelona, to where his family of six children had moved from southern Spain. At the time of the interview (late 2009), he was 46 years old and a member of staff with the Barcelona metro company (TMB), working both in public service and as a train driver.

Andrés took vocational training (FP1, the equivalent to what is now known in in Spain as formación profesional de grado medio). However, when Andrés was studying in the 1990s, FP1 was taken from the age of 14 and lasted 2 years. Even before finishing EGB (compulsory primary education) he was working handing out flyers for a chain of jewellery stores in his home town on Saturdays. When he finished EGB, he decided to take a vocational FP1 course because he liked mechanics and thought it would be good to have a trade linked to his personal tastes. He specialised as a lathe operator, while also working part-time for the same network of jewellery stores for which he had previously been distributing advertising. At the end of FP1, his intention was to move on to FP2 (advanced vocational training, a three-year course), but the company he was working for told him that they needed him full time. So he decided to stop taking vocational studies and to work full time instead. He always aspired to work in the trade for which he had been trained, and saw the break in his career to do military service as an opportunity to leave the jewellery company and find a new form of employment. He looked for work as a turner, and even considered joining the mossos d'esquadra (regional police force), but found no 
success in the short term (the companies he sent his CV to never called back, and he failed the tests to join the police). So, on returning from military service, he ended up back working for the family that owned the jewellers where he had worked before, but this time in a video store that they also owned. While working at the video store, he received job offers from the companies where he had sent his CV, but he decided to continue with the same job.

Andrés felt that he was beginning to gain recognition in his job when the owners of the video store asked if he would like to become a salesman for the group's jewellery stores, selling products door-to-door. He was given an open-ended contract and liked his job. As the years went by, he started managing a small group of sales staff and felt that he had acquired a certain knowledge of the sector. However, his job satisfaction was truncated by the crisis that hit Spain in the 1990s. As a cost-cutting exercise, the company suggested he became self-employed, but the company would pay his contributions. However, the company eventually dismissed him in 1992, shortly after he had married. During this first period of unemployment in his life he combined unemployment benefit with informal work as a stationery salesman, which to a certain extent followed on from his previous job.

After spending more than a year unemployed, he went back to work for the same group of jewellery stores, this time in a variety of roles (as well as sales). But the company did not seem to have recovered from the effects of the crisis and he was dismissed again, although officially it was Andrés who voluntarily left the company. In this second period of unemployment he didn't receive any benefits, and he decided to set up a jewellery business together with his wife, sister and brother-inlaw. However, as a way to ensure stable family income ("so there's always money at home"), his wife continued to work for the group of jewellery stores where Andres had been working.

The insecurity of the family business, together with the fact that his wife also stopped working for the jewellery group after having her second child, led the couple to try to take new career paths. A friend told them that they could get work at the Barcelona metro company (TMB) without too many initial training requirements. What's more, the openings that TMB was offering were part-time and substitutions during the summer holidays, so they could combine this possible work with care for their jewellery business. At the end of this two-year period of unemployment, Andrés' wife also started taking vocational training as a stretcher-bearer, and she found work in the hospital where she had done her internship. So although they both started the selection process at TMB, only Andrés went on to work for the Barcelona metro company, where he was in charge of ticket sales and customer services.

Just a week after the end of his summer substitution contract, TMB offered Andrés permanent work on the night shift, with an open-ended part-time contract, which meant he could carry on tending to his jewellery business in the mornings. He continued to combine both jobs until 2006, when TMB offered him a full-time job. Andrés accepted the offer, which involved both serving the public and driving trains, and he and his wife decided to sell the jewellery business in 2007. 


\subsubsection{Case 4: Begoña's Career Path}

At the time of her interview (early 2010), Begoña was living in a town attached to metropolitan Barcelona, which between the 1950s and 1970s received a huge volume of immigrant population who arrived in Catalonia from other parts of Spain. Begoña's parents are from Extremadura, and only completed primary education.

Begoña left school at the age of 14, when compulsory education ended in Spain in the 1980s. As she failed two final year subjects, she was not awarded the Graduado Escolar leaver's certificate, and she decided to train for a trade in which she would be able to find a job relatively quickly. She wanted to study hairdressing, but her mother did not like that idea and persuaded her to take up dressmaking, which she learned informally in a neighbour's home. She was able to use this knowledge to get her first job as an apprentice at a shirt factory, where she worked for 4 years, until she was 19 . She then decided to leave the job at the factory because he didn't like it. However, the company agreed to officially declare her to have been fired, because that gave her the right to receive unemployment benefit for almost 2 years. While out of work, she took a vocational training course on dressmaking, although at the same time she used this period to pay for a hairdressing course, which was what she had really wanted to do when she left school. After this first period of unemployment, Begoña went back to working in the textile sector. She got an offer through INEM (the unemployment office), which he accepted.

In 1993, when she was 22, Begoña had her first daughter. In order to be able to take care of the baby, she got the company to 'fix the papers' so she could get unemployment benefit. She was in that situation for almost two further years. She again received a job offer from the unemployment office, but this time it was a temporary contract justified by production situation in a car factory. But once her initial temporary contract had ended, she was rehired, again on a temporary basis, and this went on until the company was no longer able to chain any more temporary contracts together. Thus began a third period of unemployment that lasted until she found work as a hairdresser (she saw an ad on the street and made enquiries). She liked her job as a hairdresser, and stills claims it is what she most wants to do, but the pay was poor. She left the hairdresser when the car factory she had worked at before called her again, this time offering her a much better wage than what she was getting as a hairdresser ("the salary was like three times more"). Once again, when the company was no longer able to chain temporary contracts together, she was out of work. During this fourth period of unemployment, she also took a vocational course, this time to work as a shop assistant. Of the different training options she could choose from, she felt this was best because the hours were most compatible with looking after her daughter, unlike the car factory, where she had to work shifts. Through her internship as a shop assistant, she made contact with the company where she is working now. After 2 years on a temporary contract, the company hired her on a fixed-term basis in 2006. In 2007, her second daughter was born. After maternity leave, she asked to work fewer hours in order to care for her daughter, which the company agreed to, but moved her to a different store against her will. 


\subsubsection{The Inter-Configurative Biographical Analysis: Case Comparison as an Analytical Key}

As we noted in point 2.2 of this chapter, inter-configurative analysis of the comparative biographical perspective implies, on the one hand, contrast of case studies to comparatively analyse how similarities and differences on the macro and mesosocial scales tend to condition or cause life courses in each single case, and, on the other hand, comparing subjects' experiences and choices on that path, to finally deal with the particularities caused by the external conditions and actions in the different stages of the compared life courses. Likewise, in making this contrast, we can and must identify the transitions and turning points or biographical bifurcations to identify how they are caused and what part they play in the direction taken by the different life courses, managing in different ways the contingency and linking over time of advantages or disadvantages in order to appreciate how inequalities are embodied in life stories.

When comparing the cases studied here, we note that in the Argentine workers' life stories it is clear how the macro and mesosocial scales are present, causing and conditioning different forms of employment in different periods. Enrique and Rubén started working for the first time in the 1970s, at which time the military junta (1976-1983) implemented a neoliberal welfare system that would have a long-term impact on the labour market, without immediately making any major changes in terms of labour policy and reform. In the 1980s, both workers found formal employment in a public company, until they were both dismissed in the 1990s as a result of the privatisation policies applied by the welfare system of the time. Their life courses reflect the major transformations that were applied under a neoliberal welfare model that considerably 'shrunk' the state, destabilised many of its companies, dismissed a large number of public employees, liberalised the economy, substantially limited workers' rights and critically transformed the labour market into one that was beginning to show high unemployment rates (Azpiazu and Schorr 2010).

This is evidence of how the macrosocial scale connects with the mesosocial scale, not only generating opportunities at certain times and restricting them at others, but also causing events that lead to disruptions and bifurcations of career paths. The macrosocial scale, associated to neoliberal welfare states, is thus condensed with the mesosocial scale in terms of institutional policies that reveal the shift between the existence and promotion of a sizeable number of companies and public jobs, and privatisation and the dismissal of state employees who are no longer able to work for these firms. The transitions between these macro and mesosocial processes lead in both cases to moments of disruption, which are both favourable when they enter formal public employment and unfavourable when they lose these jobs and resort to subsistence self-employment.

In the Spanish workers' life stories, three main structuring factors can be identified. The first, and possibly most obvious, is the effect of the gender variable on career paths. Begoña's daughters evidently feature prominently in her story, and her career path is built around the possibilities of combining paid work with care for her 
children. The influence of gender on career paths is not one of the goals of this chapter, but should nevertheless be noted. Secondly, the influence of the crisis of the 1990s is evident, as it was in the Argentinian cases, but only with regard to Andrés. Begoña's path is less affected by the crisis, partly because her situation was already unstable even before the crisis, and partly because its worst years (1992 to 1995) coincided with her becoming a mother and preferring to take care of her daughter. Thirdly, and perhaps most importantly in relation to the discussion of inequality in career paths, is the role of the (un)employment benefit system in Spain. Its evident lack of resources, compared to other European systems, and the neo-liberal reforms implanted since before the 1990s (Banyuls et al. 2009) should not conceal the important role that social welfare plays in labour transitions and trajectories in Spain (Miguélez and Recio 2010). These effects are very clear in both stories. They both involve the possibility of receiving vocational training while out of work. In Begoña's case (and in that of Andrés' wife) this training helped to find work and also led to a certain change of career. Also in both cases, unemployment benefits allowed our respondents to obtain resources that somehow alleviated their lack of income, albeit clearly insufficiently as demonstrated by Andrés' need to combine his benefit with informal employment.

The design of institutional support for unemployment is a good example of the connections between the macrosocial scale and the mesosocial scale in Spain. The existence of an unemployment benefit system is characteristic of European Union member states, but the institutional methods used to provide it are highly varied (Lefresne 2010). In Spain, there are very few conditions on the way unemployment benefits can be used, which allows (and at the same time obliges) people without work to choose from a relatively high number of options (López-Andreu and Verd 2011a). This flexibility means benefits can be used by workers as a protection mechanism against various contingencies in life, allowing them to deal with situations for which these benefits are not specifically designed, but for which there are no other benefits that do serve that purpose, unlike in other countries (Bartelheimer et al. 2012). These resources are used due to the weakness or absence of other social policies that are more adapted to specific situations (maternity pay, scholarships, etc.) and continuous instability in certain types of career paths, as is so manifestly the case with Begoña.

Meanwhile, turning to the experiences, judgements, choices and actions of the subjects during their career paths, we note that although we have found similarities in terms of the possibilities, conditions and bifurcations that the macro and mesosocial scales tend to produce, when we specifically focus on microsocial aspects, our cases present differences both within and between countries.

If we compare then the paths of the Argentine workers, we observe that while Enrique finished his studies at an industrial school and centred his labour transitions on the crane operating skills that he had acquired during some of his earliest jobs, Rubén entered the labour world without completing compulsory secondary education and with no specific 'know-how'. The possession or not of labour skills, acquired personally rather than at professional training institutes, is a key factor behind these career paths. While Enrique's trade meant he could change jobs 
whenever he found positions at companies that offered better pay, Rubén's lack of knowledge meant he was permanently in and out of work and changing between activities and sectors without ever settling anywhere. Moreover, Rubén suffered accidents at work due the physicality that his jobs entailed, a situation that Enrique did not have to go through.

This chain of individual factors that affect the course and differentiation of these trajectories, one eminently focused on a trade and conditions shifting between instability and formality, and another based on seizing informal opportunities whenever they arose, only became equated under an institutional state policy that fostered formal work, i.e. when they both find jobs in the public oil company. The government's withdrawal from labour affairs meant they had to start out again in the context of an economy in crisis and a job shortage. Left to their own devices, their transitions send them back in different directions. Although both workers left YPF to go into subsistence self-employment, over time Enrique was able to use his trade to get his life course back on track, while Rubén continued to work informally with constant interruptions due to unemployment.

Something similar happened in the Spanish case. Although Andrés had no institutional certification of his 'trade' as a jeweller, his accumulated experience allowed him to overcome the economic crisis of the 1990s through self-employment. However, as in the case of Enrique in Argentina, his own resources were insufficient to cope with this project without help from his wife. This is 'subsistence' selfemployment, which continued until it was possible for the family to obtain a more stable and less 'sacrificed' source of income. Andrés' departure from selfemployment, however, is different from Enrique's, since it does not involve a radical change of sector (he had experience of sales and dealing with clients, which was undoubtedly taken into account when TMB hired him to serve the public). As for Begoña, as she had nothing more than a school leaver's certificate (she would later obtain a Graduado Escolar by her own account), she was forced to accept unsatisfying jobs with very low pay. However, unlike Rubén, Begoña does have a trade in mind (being a hairdresser), which guides her choices and actions once she has achieved a certain level of financial autonomy. During her first period of unemployment, she invests her unemployment benefit in paying for a private academy that provides her with the training she needs to become a hairdresser. Her time in this trade is fleeting, for she is disappointed by what she considers to be very poor pay, but at the time of the interview she insists that she has not given up hope of one day becoming a self-employed hairdresser, which takes us back to the need to gather the necessary resources in order to set up one's own business. While in Rubén's case, employment for a brief period as an operator in a state-owned company involved no opportunity to acquire a specific skill, and merely the chance to get out of informal work and unemployment, in Begoña's case, periods without work constitute certain opportunities to gain skills through vocational training, which is what she achieves when doing work experience in a supermarket, which leads to a radical change of sector and the beginning of a completely new career.

In the Argentinian case, Enrique and Rubén's stories show that it is only when there is an institutional government policy that promotes formal work that it is 
possible to somehow reverse the weight of occupational qualifications (acquired individually or not) on career paths. The Spanish cases show that the (negative) effect of a lack of skills for employment can partly be reversed through non-formal vocational training (called occupational training, in Spain). Although the debate on the real effects of occupational training on the careers of unemployed people is still open (Miguélez and Recio 2010; Verd and López-Andreu 2014), some data shows that if it has any positive effect at all then this is on people with more unstable career paths and fewer qualifications (López-Andreu and Verd 2011b).

Finally, it is useful to make a final consideration from the comparative analysis of the four trajectories analysed in this chapter. Although the foregoing paragraphs have highlighted the influence that a society's welfare and employment systems (macro level) and institutional social protection schemes (meso level) have on-and connect with-individual actions and decisions (micro level), our analysis of life stories shows that another key element that links different states stems from the inequalities and resources with which people start out (private family and personal resources). This aspect was not the focus of our analysis, but we should note that the longitudinal accumulation of advantages and disadvantages, and in general the production and reproduction of social inequality, is explained by this unequal distribution of resources that affects individuals in such dissimilar ways. This inequality of resources is related to people's positions in the social structure as a result of tax and income policies established by governments, a proper analysis of which would require the same amount of space that has been used thus far.

\subsection{Final Thoughts. The Development of an International Comparative Perspective Based on Analysis of Unequal Life Courses}

In this chapter, we have noted the relevance of a study of social inequalities from a comparative biographical perspective, since it offers unrivalled methodological advantages by linking across time aspects that are situated on the macrosocial level (structural conditions and processes) with others on the mesosocial level (the role of institutions) and the microsocial level (individual practices, representations, experiences and strategies, if any). This diachronic view of inequalities is shown to be relevant, as it can be used to identify how deprivation and privilege are produced, reproduced and transmitted over time.

We also note that the comparative biographical approach can be used to identify how those events, transitions and stages that constitute moments of disruption to life courses fit with the accumulation of advantages and disadvantages, revealing the relevance to these life courses of the bifurcations caused by specific events in a subject's life (an accident, motherhood) or by events that are external to them (an institutional policy to promote or reduce employment). We have also shown evidence in favour of intra-configurative and inter-configurative biographical 
comparison and have presented a specific comparative exercise to showcase the potential of the proposed methodological perspective.

We shall therefore end by pointing out that, as has been demonstrated, the comparative biographical perspective and its intra and inter-configurative analysis are a proven method for revealing the particularities caused by external conditions and subjective actions in the different stages of comparative life stories, highlighting the relevance of social agents for understanding how, in the face of different or similar macrosocial and mesosocial contexts, different life courses are constructed that are the result of a series of advantages and disadvantages that configure and reconfigure social inequalities over time. 


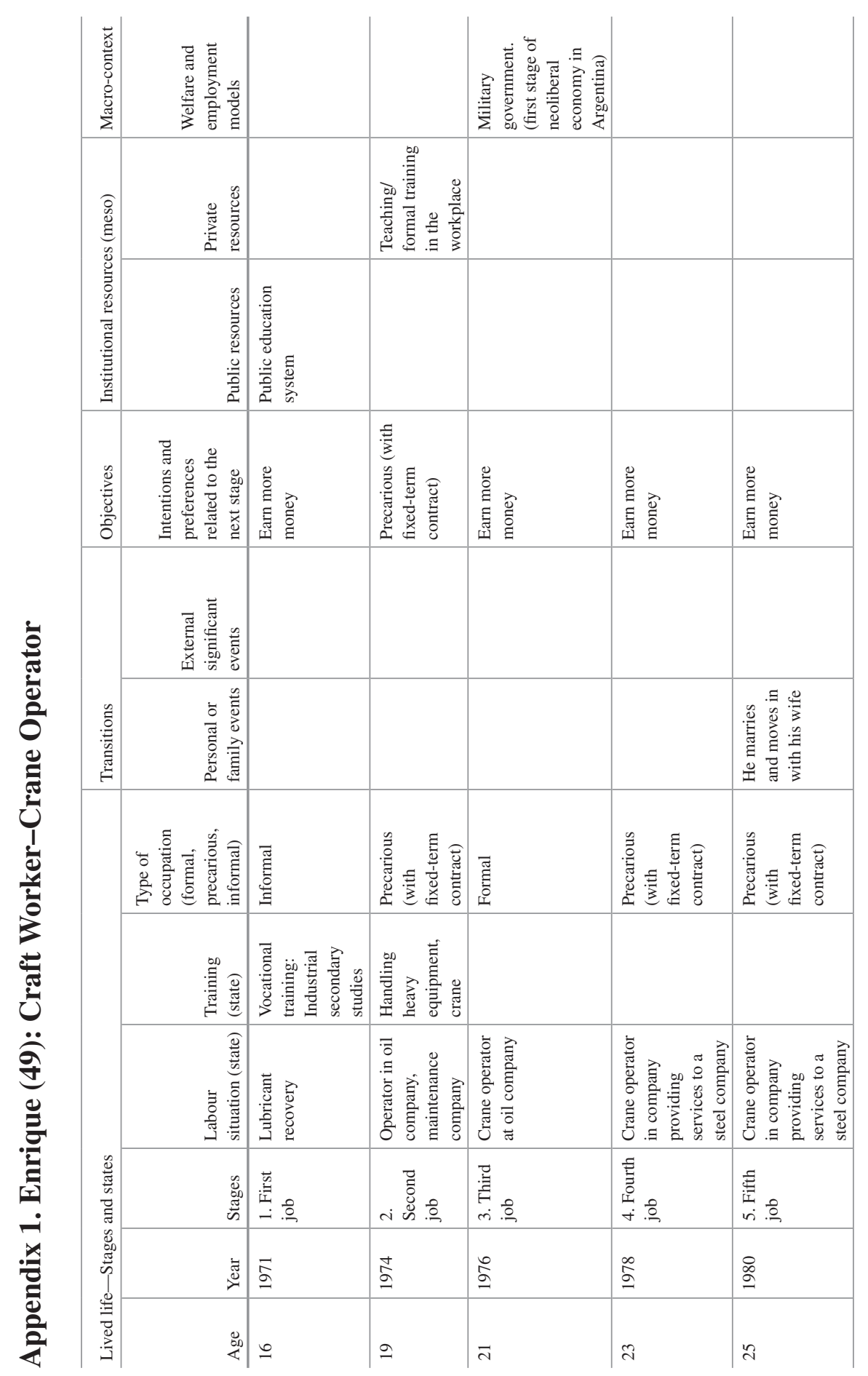




\begin{tabular}{|c|c|c|c|}
\hline & & 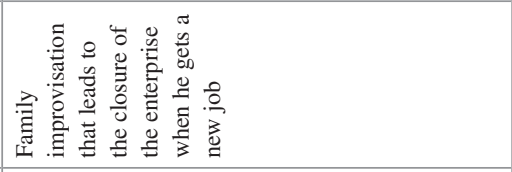 & \\
\hline & 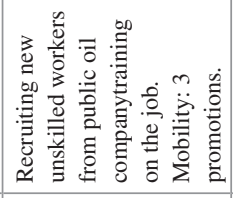 & & \\
\hline \multirow[t]{3}{*}{ 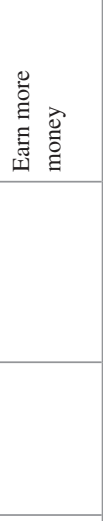 } & & 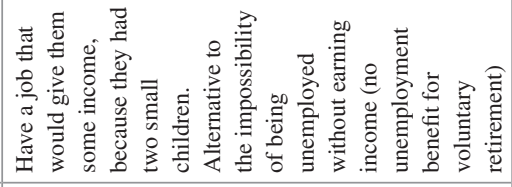 & 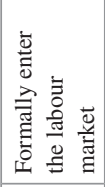 \\
\hline & 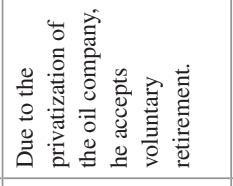 & & \\
\hline & & 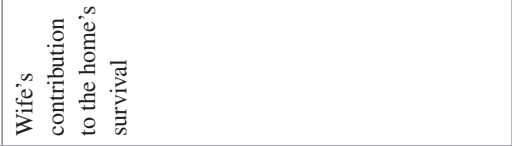 & \\
\hline 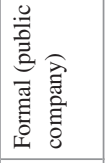 & 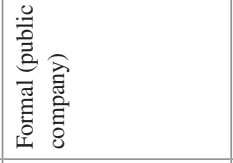 & 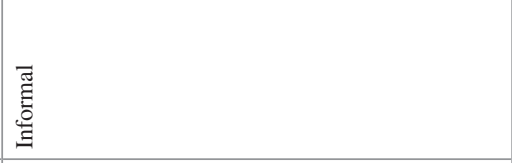 & 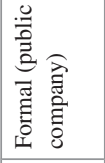 \\
\hline 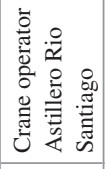 & 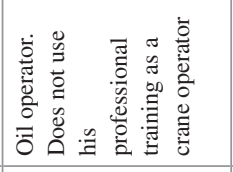 & 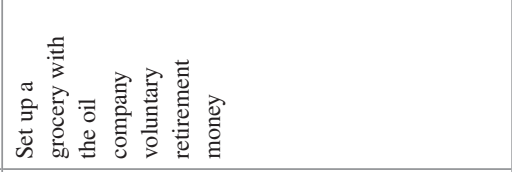 & 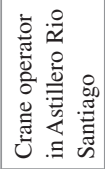 \\
\hline 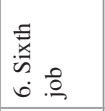 & 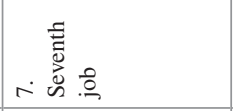 & 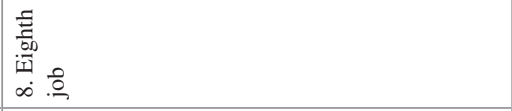 & 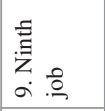 \\
\hline$\stackrel{\infty}{\varrho}$ & $\begin{array}{l}\stackrel{\circ}{\varrho} \\
\stackrel{-}{\circ}\end{array}$ & $\stackrel{\curvearrowright}{\sigma}$ & $\begin{array}{l}\pi \\
\hat{\sigma} \\
\sigma \\
\sigma\end{array}$ \\
\hline $\bar{\imath}$ & $\bar{m}$ & $\stackrel{\infty}{m}$ & 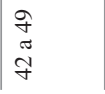 \\
\hline
\end{tabular}




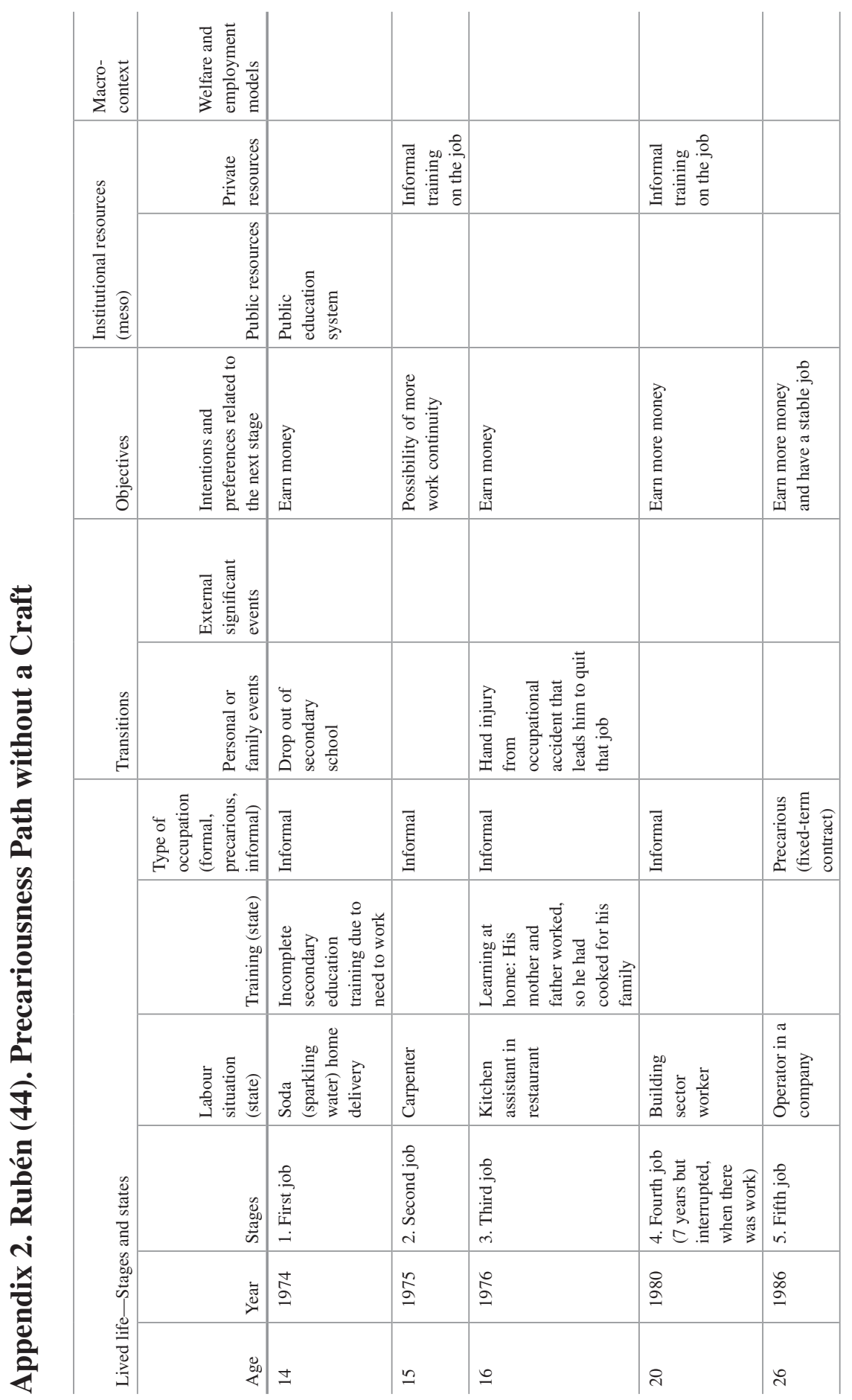




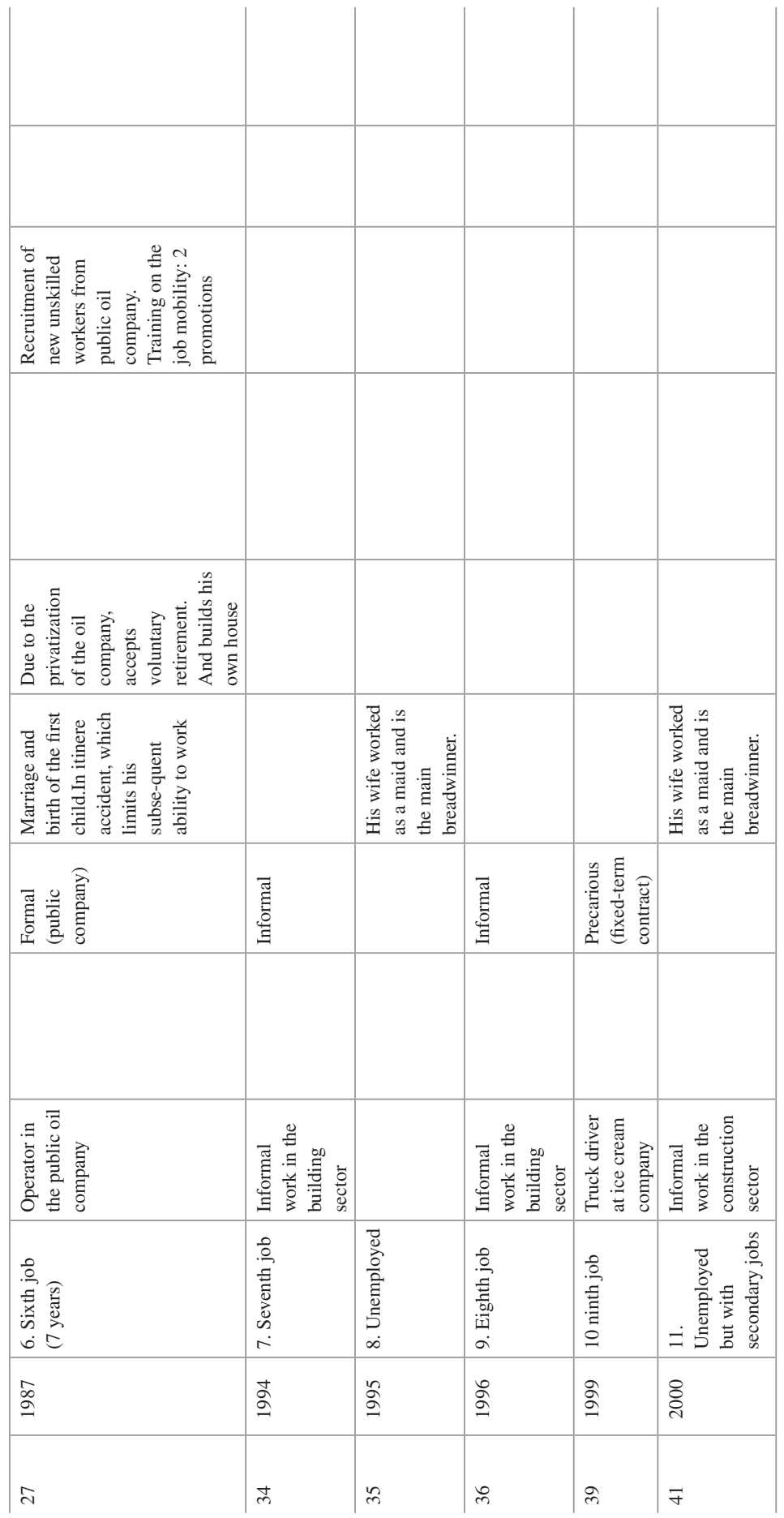




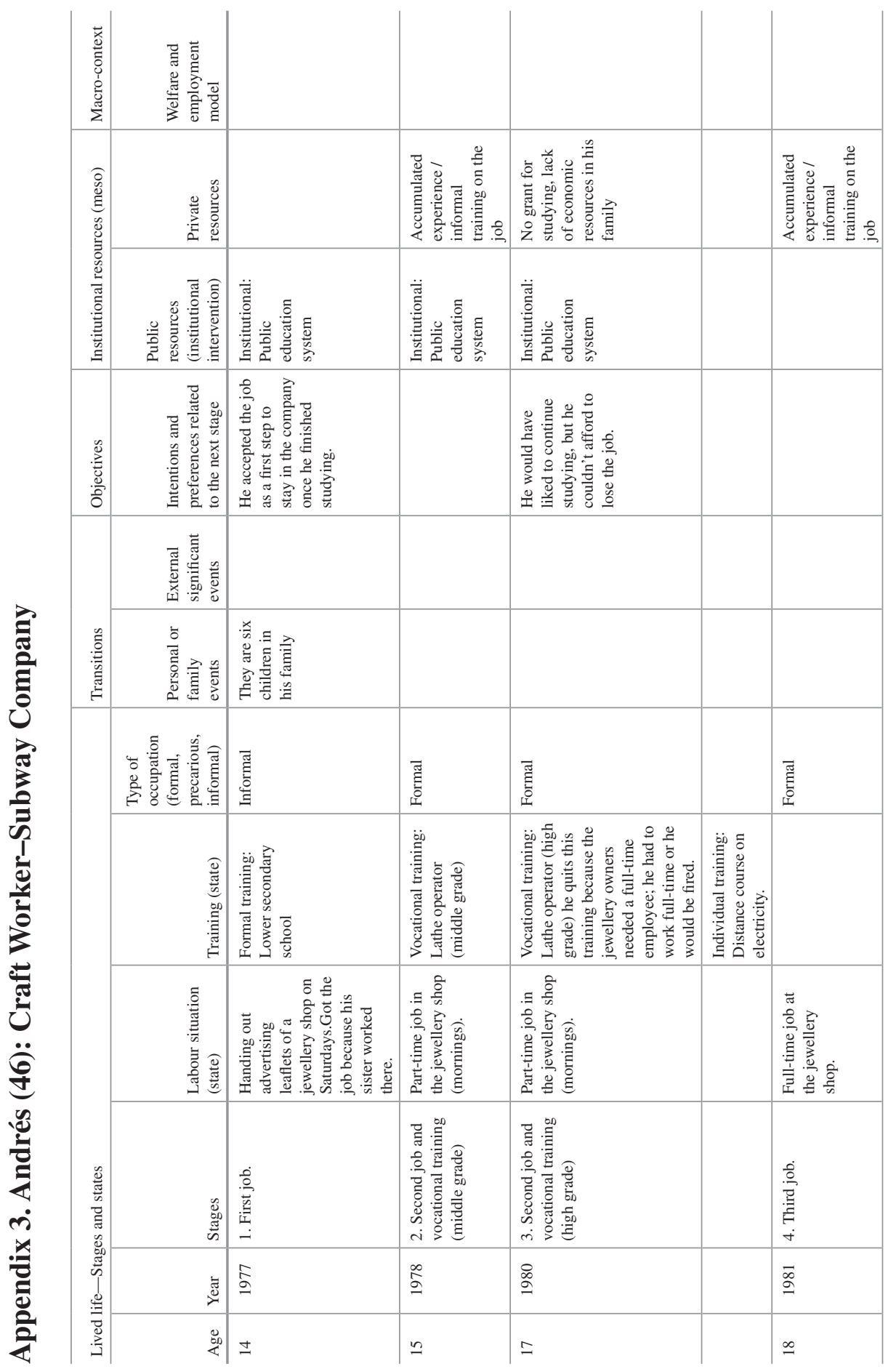




\begin{tabular}{|c|c|c|c|c|}
\hline & 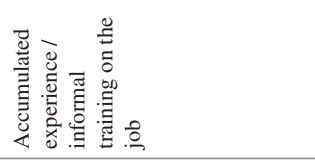 & 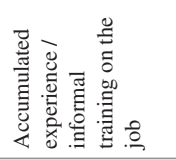 & & \\
\hline & & & & 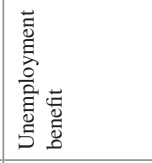 \\
\hline \multirow[t]{2}{*}{ 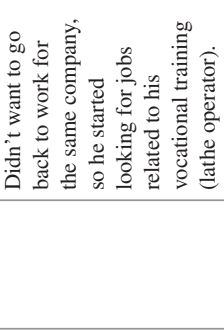 } & 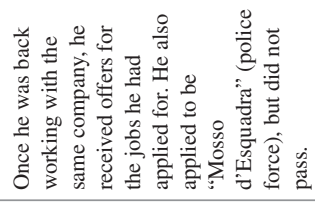 & & & \\
\hline & & & 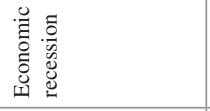 & 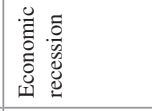 \\
\hline \multirow[t]{3}{*}{ 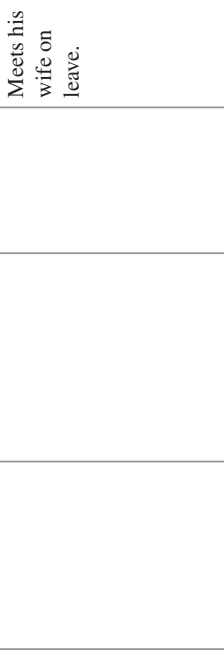 } & & & 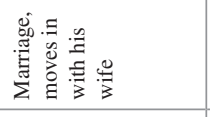 & \\
\hline & 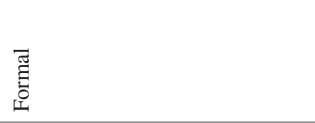 & 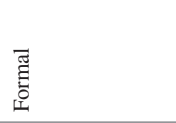 & 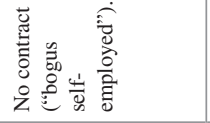 & \\
\hline & 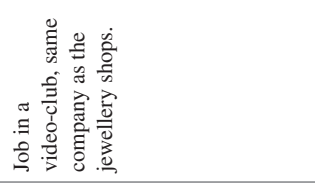 & 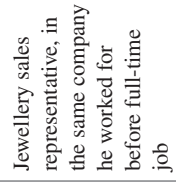 & 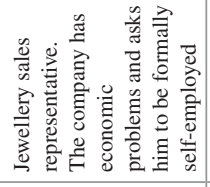 & 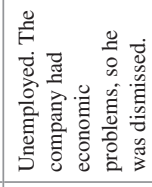 \\
\hline 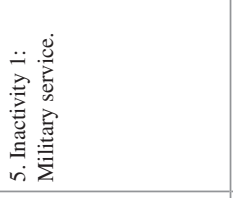 & 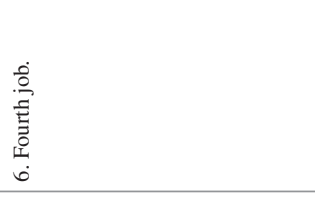 & 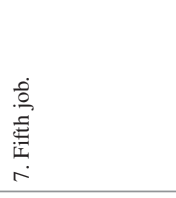 & 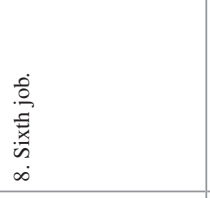 & 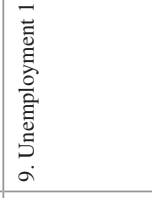 \\
\hline$\stackrel{\curvearrowright}{\stackrel{2}{\varrho}}$ & $\stackrel{ \pm}{\stackrel{\Xi}{\varrho}}$ & $\stackrel{\check{\varrho}}{\stackrel{0}{2}}$ & $\bar{\Xi}$ & ऽ̆ \\
\hline$\stackrel{2}{2}$ & $\vec{\sim}$ & $\stackrel{\sim}{\sim}$ & $\stackrel{\infty}{\sim}$ & ते \\
\hline
\end{tabular}




\begin{tabular}{|c|c|c|c|c|c|}
\hline 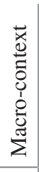 & 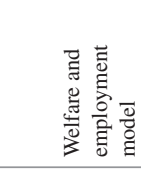 & 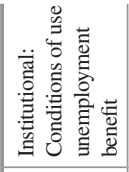 & & & \\
\hline \multirow{2}{*}{ 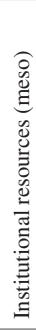 } & 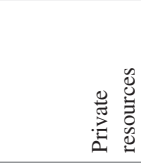 & & & 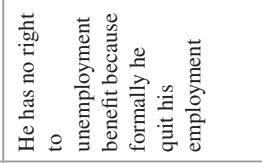 & \\
\hline & 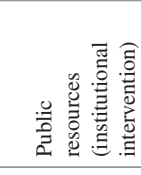 & 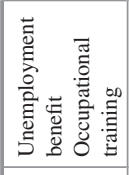 & & & \\
\hline 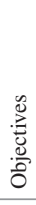 & 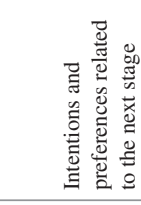 & & & 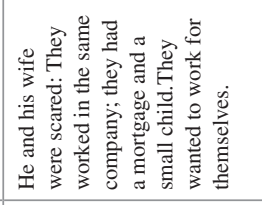 & 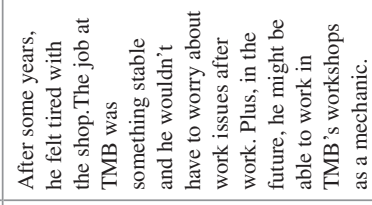 \\
\hline & 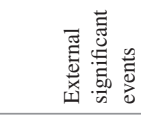 & 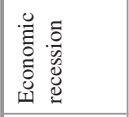 & 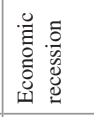 & 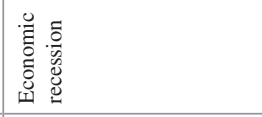 & \\
\hline & 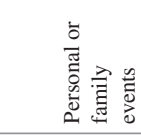 & & 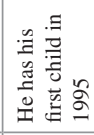 & & 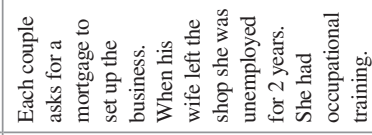 \\
\hline \multirow{6}{*}{ 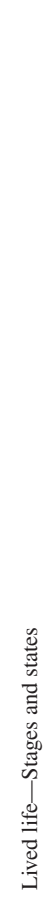 } & 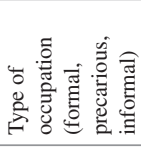 & 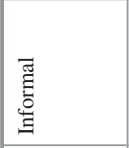 & 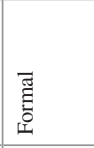 & & 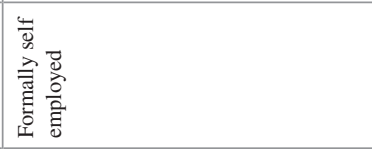 \\
\hline & 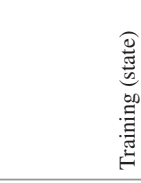 & 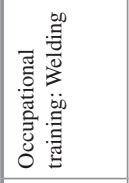 & & & \\
\hline & 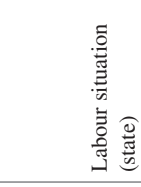 & 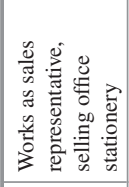 & 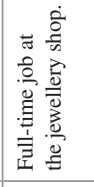 & 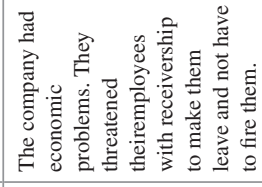 & 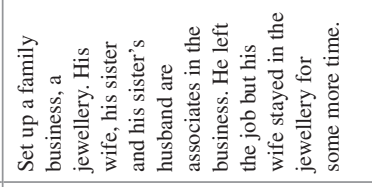 \\
\hline & 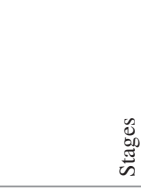 & 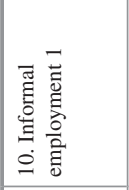 & 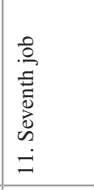 & 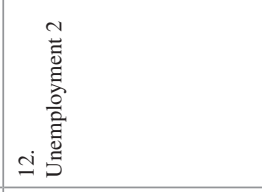 & 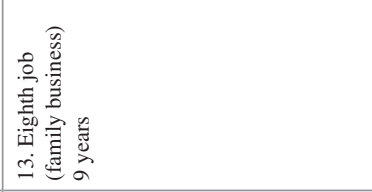 \\
\hline & $\stackrel{\Xi}{0}$ & $\stackrel{\sigma}{\sigma}$ & $\tilde{\Omega}$ & $\stackrel{2}{2}$ & $\hat{\mathrm{a}}$ \\
\hline & $\underset{8}{8}$ & ते & in & $m$ & $\stackrel{ \pm}{m}$ \\
\hline
\end{tabular}




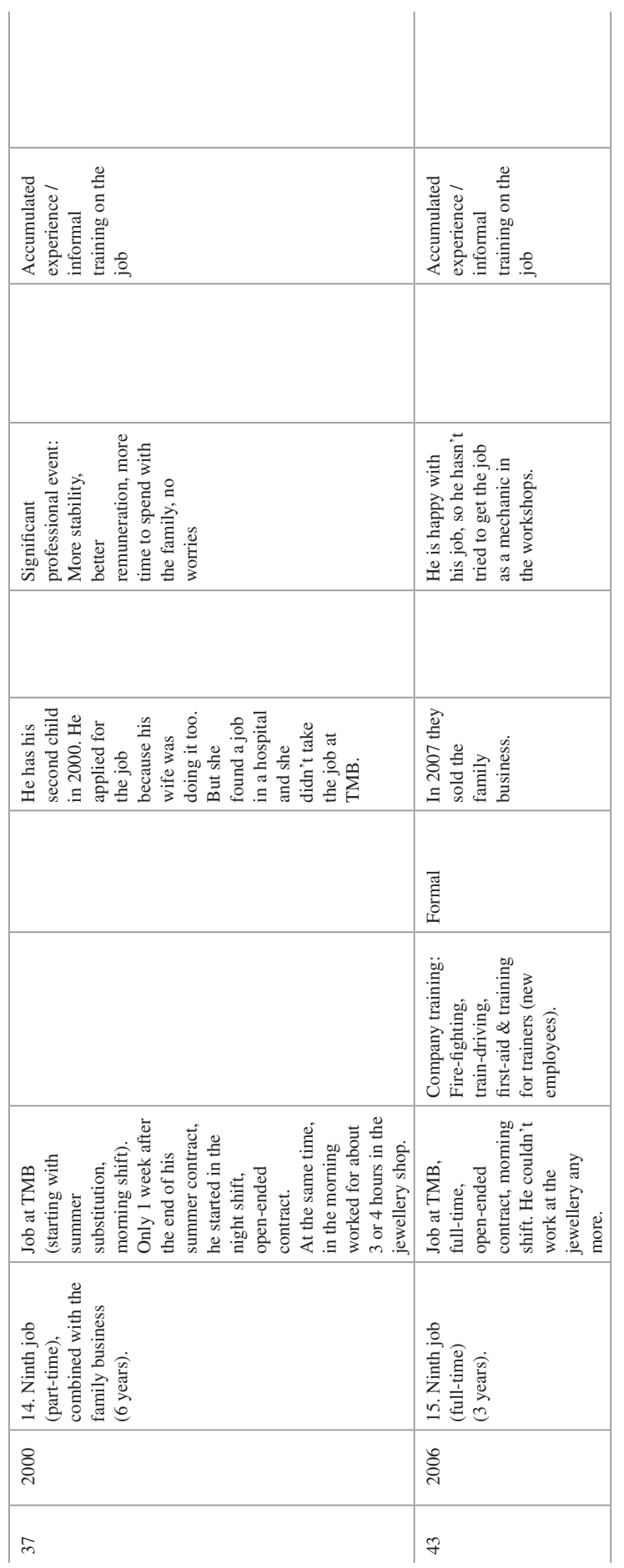




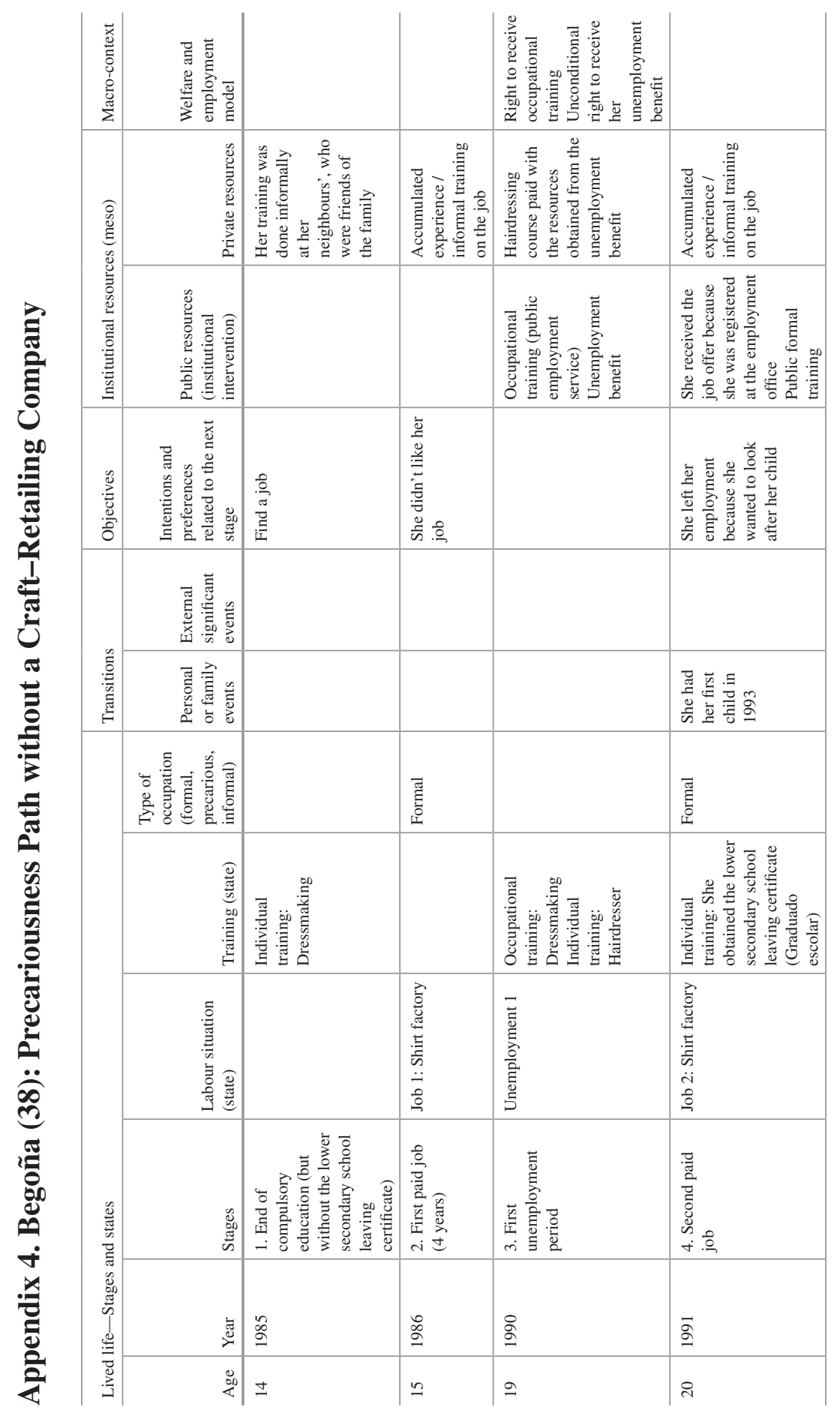




\begin{tabular}{|c|c|c|c|c|c|}
\hline 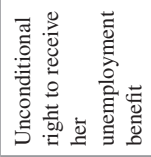 & & 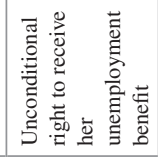 & & & 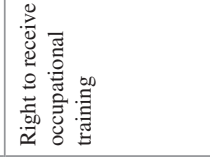 \\
\hline & 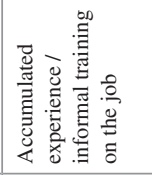 & & 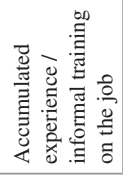 & 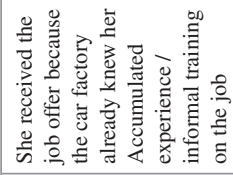 & 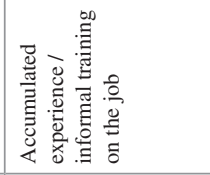 \\
\hline \multirow[t]{5}{*}{ 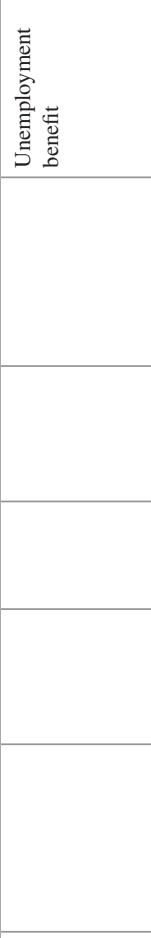 } & 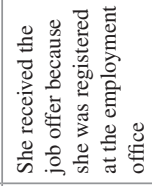 & 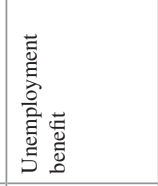 & & & 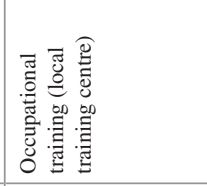 \\
\hline & & & 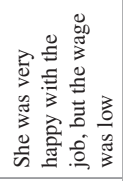 & 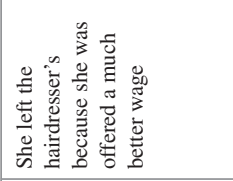 & 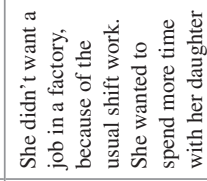 \\
\hline & 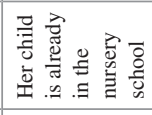 & & & & \\
\hline & 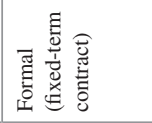 & & 丞 & 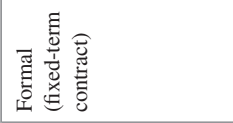 & \\
\hline & & & & & 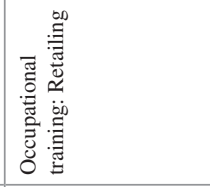 \\
\hline 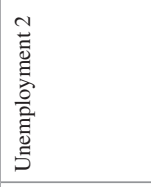 & 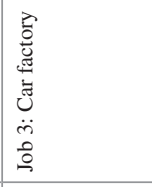 & 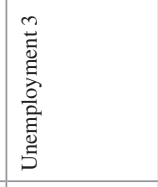 & 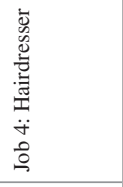 & 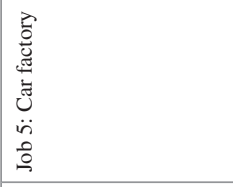 & 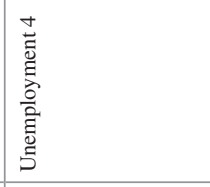 \\
\hline 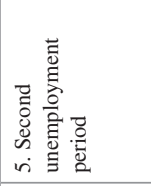 & 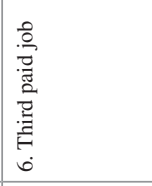 & 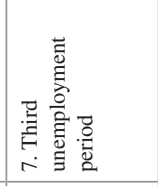 & 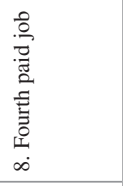 & 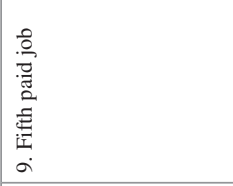 & 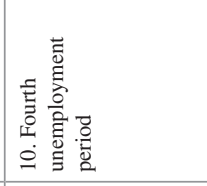 \\
\hline ๙̊ & $\stackrel{\swarrow}{\varrho}$ & 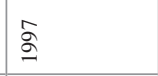 & ڤ & ఫ్ڤ & ڤે̀ \\
\hline$\approx$ & $\stackrel{+}{\sim}$ & $\stackrel{\sim}{\sim}$ & $\stackrel{\infty}{\sim}$ & లి & लె \\
\hline
\end{tabular}




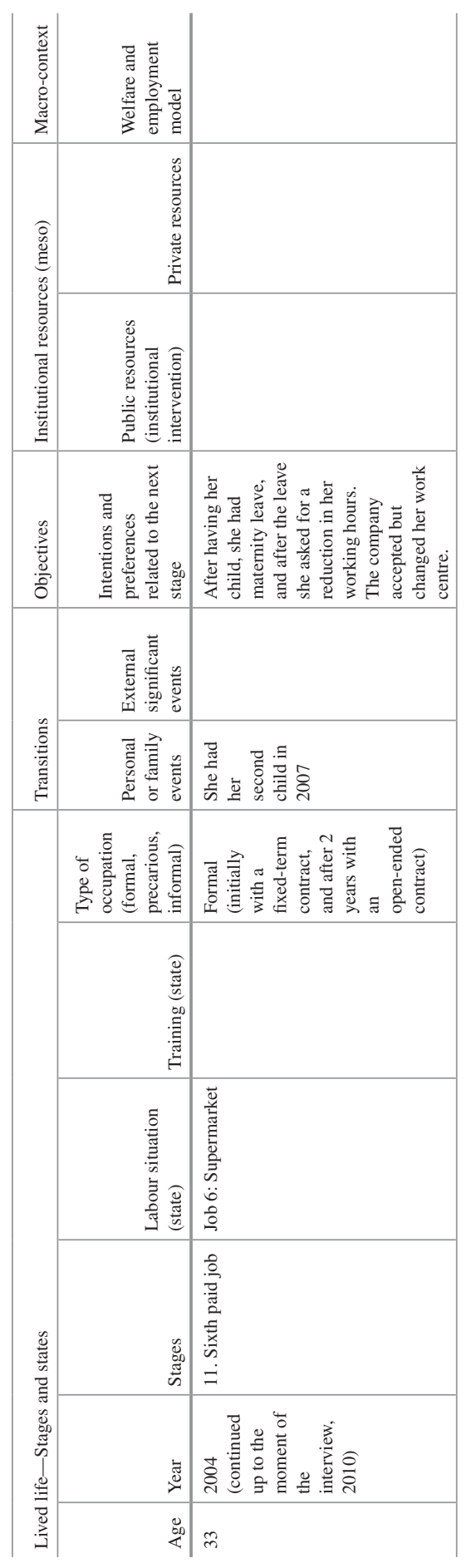




\section{References}

Anxo, D., Bosch, G., \& Rubery, J. (2010). Shaping the life course: A European perspective. In D. Anxo, G. Bosch, \& J. Rubery (Eds.), The welfare state and life transitions: An European perspective (pp. 1-77). Cheltenham: Edward Elgar.

Azpiazu, D., \& Schorr, M. (2010). Hecho en Argentina. Industria y Economía, 1976-2007. Buenos Aires: Siglo XXI Editores.

Banyuls, J., Miguelez, F., Recio, A., Cano, E., \& Lorente, R. (2009). The transformation of the employment system in Spain: Towards a Mediterranean neoliberalism. In G. Bosch, S. Lehndorff, \& J. Rubery (Eds.), European employment models in flux. A comparison of institutional change in nine European countries (pp. 247-269). New York: Palgrave.

Bárcena, A., \& Prado, A. (2010). Heterogeneidad estructural y brechas de productividad: de la fragmentación a la convergencia. In CEPAL (Ed.), La hora de la igualdad. Brechas para cerrar, caminos por abrir (pp. 91-130). Santiago de Chile: CEPAL.

Bartelheimer, P., Verd, J. M., Lehweß-Litzmann, R., López-Andreu, M., \& Schmidt, T. (2012). Unemployment, intervention and capabilities. A comparative study of Germany and Spain. Transfer, 18(1), 31-44.

Bertaux, D. (1997). Les récits de vie. París: Nathan.

Bertaux, D. (1980). L'approche biographique: sa validité méthodologique, ses potentialités. Cahiers Internationaux deSociologie, 69, 197-225.

Breckner, R. (2007). Case-Oriented Comparative Approaches: The Biographical Perspective as Opportunity and Challenge in Migration Research. In K. Schittenhelm (Ed.), Concepts and Methods in Migration Research. Conference Reader (113-147). Retrieved from www.culturalcapital.net. Accessed on July 2nd, 2018.

Bynner, J. (2005). Rethinking the youth phase of the life-course: the case for emerging adulthood? Journal of Youth Studies, 8(4), 367-384.

Clandinin, J. D., \& Connelly, M. F. (1994). Personal experience methods. In N. K. Denzin \& Y. S. Lincoln (Eds.), Handbook of qualitative research. Thousand Oaks, California: Sage.

Diewald, M., \& Mayer, K. U. (2008). The Sociology of the Life Course and Life Span Psychology. DIW Discussion Paper 772, Berlin.

Elder, G. H. (1985). Perspectives on the life course. In G. H. Elder (Ed.), Life course dynamics. Ithaca: Cornell University Press.

Elder, G. H., Johnson, M. K., \& Crosnoe, R. (2004). The emergence and development of the life course theory. In J. T. Mortimer \& M. J. Shanahan (Eds.), Handbook of the life course. New York: Springer.

Eisenhardt, K. (1989). Building theories from case study research. Academic of Management Journal, 14(14), 532-550.

Gerring, J. (2007). Case study research. Principles and practices. New York: Cambridge University Press.

Giele, J. Z., \& Elder, G. H. (1998). Life course research: Development of a field. In J. Z. Giele \& G. H. Elder (Eds.), Methods of life course research. Qualitative and quantitative approaches (pp. 5-27). Thousand Oaks, California: Sage.

Giménez, G. (2012). El problema de la generalización en los estudios de caso. Cultura y representaciones sociales, 7, 40-62.

Goffman, E. (1981). La presentación de la persona en la vida cotidiana. Buenos Aires: Amorrortu.

Jovchelovitch, S., \& Bauer, M. W. (2000). Narrative interviewing. In M. W. Bauer \& G. Gaskell (Eds.), Qualitative researching with text, image and sound (pp. 57-94). London: Sage.

Lahire, B. (2002). Portraits sociologiques. Dispositions et variations individuelles. Paris: Nathan.

Lefresne, F. (2010). Unemployment benefit systems in Europe and North America: Reforms and crisis. Brussels: ETUI.

López-Andreu, M., \& Verd, J. M. (2011a). Usos y efectos de la protección al desempleo en España. Resultados en base a la perspectiva de las capacidades. Cuadernos del Mercado de Trabajo, 7, 14-21. 
López-Andreu, M., \& Verd, J. M. (2011b). Les effets de la formation diffèrent selon les parcours sur le marché du travail: 1'exemple catalan. Formation-Emploi, 113, 63-79.

Miguélez, F., \& Recio, A. (2010). The uncertain path from the Mediterranean welfare model in Spain. In D. Anxo, G. Bosch, \& J. Rubery (Eds.), The welfare state and life transitions (pp. 284-308). Cheltenham: Edward Elgar Publishing.

Mortimer, J. T., \& Shanahan, M. J. (Eds.). (2004). Handbook of the life course. New York: Springer.

Muñiz Terra, L., \& Rubilar, G. (2018). La perspectiva biográfica en clave comparativa: Consideraciones metodológicas a partir de estudios de caso de desigualdades sociales en Chile y Argentina (Actas XIX ISA world congress of sociology. 15 to 21 of July 2018). Toronto: Canada.

Passeron, J., \& Revel, J. (2005). Penser par cas. Paris: Éditions de l'École des Hautes Études en Sciences Sociales.

Piovani, J., Rausky, M. E., \& Santos, J. (2011). Definiciones metodológicas del case study en publicaciones tempranas del American Journal of Sociology (1915-1934). In E. C. Gallegos, R. M. Lince, \& Campillo (Comp.) (Eds.), Reflexiones latinoamericanas sobre metodología de las ciencias sociales (Vol. I, pp. 180-205). Ciudad de México: Unison-UNAM.

Przeworsky, A., \& Teune, H. (1970). The logic of comparative social inquiry. New York: John Wiley.

Ragin, C. C., \& Becker, H. (1992). What is a case? Exploring the foundations of social inquiry. Cambridge: Cambridge University Press.

Rawls, J. (1997). Teoría de la justicia. México: FCE.

Reygadas, L. (2004). Las redes de la desigualdad: un enfoque multidimensional. Política y Cultura, $22,7-25$.

Rosenthal, G. (2004). Biografical research. In C. Seale, G. Gobo, J. F. Gubrium, \& D. Silverman (Eds.), Qualitative research practice (pp. 48-64). Londres: Sage.

Runyan, W. (1984). Life histories and psychobiography. Explorations in theory and method. New York: Oxford University Press.

Savage, M. (2014). A new model of social class? Findings from BBC's great British class survey experiment. Sociology, 47(2), 219-250.

Schmid, G. (1998). Transitional labour markets: A new European strategy. In Discussion paper FS I 98-206. Wissenschaftszentrum: Berlin für Sozialforschung.

Schmid, G. (2006). Social risk management through transitional labour markets. Socio-Economic Review, 4, 1-33.

Schütz, A. (1987[1971). Le chercheur et le quotidien. Paris: Méridiens Klincksieck.

Stake, R. (1994). Qualitative case studies. In N. K. Denzin \& Y. Lincoln (Eds.), Handbook of qualitative research (pp. 443-466). Thousand Oaks, California: Sage.

Stake, R. (1999). The art of case study research. Thousand Oaks, California: Sage.

Stake, R. (2005). Qualitative Case Studies. Thousand Oaks, California: Sage.

Thomas, W. I., \& Znaniecki, F. (1918). The polish peasant in Europe and America. Boston: Gorham Press.

Tilly, C. (2000). La desigualdad persistente. Buenos Aires: Manantial.

Therbon, G. (2006). Inequalities of the world. London: Verso.

Thompson, P. (2004). Researching family and social mobility with two eyes: Some experiences of the interaction between qualitative and quantitative data. International Journal of Social Research Methodology, 7(3), 237-257.

Vandecasteele, L. (2010). Life course risks or cumulative disadvantage? The structuring effect of social stratification determinants and life course events on poverty transitions in Europe. European Sociological Review, 27(2), 246-263.

Varesi, G. (2009). La configuración del modelo postconvertibilidad: Políticas y clases. Algunas claves para su caracterización, 2002-2007. Cuestiones de Sociología, 5-6, 27-54.

Verd, J. M., \& López-Andreu, M. (2011). The rewards of a qualitative approach to life-course research. The example of the effects of social protection policies on career paths. Forum Qualitative Sozialforschung / Forum: Qualitative Social Research, 12(3), 15. 
Verd, J. M., \& López-Andreu, M. (2014). Capabilities as an assessment tool for social policies. The example of the effects of non-formal training measures in Spain. In H.-U. Otto \& H. Ziegler (Eds.), Critical social policy and the capability approach (pp. 207-230). Opladen: Barbara Budrich.

Vielle, P., \& Walthery, P. (2003). Flexibility and social protection: Reconciling flexible employment patterns over the active life cycle with security for individuals. Dublin: European Foundation for the Improvement of Living and Working Conditions.

Wilkinson, R., \& Pickett, K. (2009). The Spirit level. London: Allen Lane.

Yin, R. K. (1995). Applications of case study research. Thousand Oaks, California: Sage.

Yin, R. K. (2014). Case study research. Design and methods (5th ed.). Thousand Oaks, California: Sage.

Open Access This chapter is licensed under the terms of the Creative Commons Attribution 4.0 International License (http://creativecommons.org/licenses/by/4.0/), which permits use, sharing, adaptation, distribution and reproduction in any medium or format, as long as you give appropriate credit to the original author(s) and the source, provide a link to the Creative Commons licence and indicate if changes were made.

The images or other third party material in this chapter are included in the chapter's Creative Commons licence, unless indicated otherwise in a credit line to the material. If material is not included in the chapter's Creative Commons licence and your intended use is not permitted by statutory regulation or exceeds the permitted use, you will need to obtain permission directly from the copyright holder.

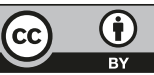

